\title{
A HISTOCHEMICAL STUDY OF THE ESTERASES OF THE ADRENAL MEDULLA OF THE RAT ${ }^{1}$
}

\author{
JOHN M. ALLEN ${ }^{2}$ \\ Department of Zoology, University of Michigan \\ OLAVI ERÄNKÖ ${ }^{3}$ \\ Department of Anatomy, University of Helsinki \\ ROBERT L. HUNTER ${ }^{4}$ \\ Department of Anatomy, University of Michigan
}

THIRTEEN FIGURES

Two different types of parenchymal cells have been demonstrated in the mammalian adrenal medulla after histochemical treatment for the visualization of acid phosphatase (Eränkö, '51, '52; Picard and Vitry, '54; Picard et al., '55), fluorescence after fixation in calcium-formol (Eränkö, '51, '52), reduction of ammoniacal silver nitrate after the same fixation (Eränkö, '51, '52), color formation after treatment with potassium iodate (Hillarp and Hökfelt, '53, '54, '55), esterase (Coutinho

${ }^{1}$ Since it came to the attention of the authors that work upon this problem was progressing independently in the three laboratories it was deemed desirable to publish our results jointly.

"Work supported by a grant from the National Cancer Institute of the U.S. Public Health Service (C-2751). Samples of DFP were obtained through the courtesy of Dr. B. J. Jandorf, The Army Chemical Center, Maryland. Samples of Ro 2-0683 and Ro 2-1250 were obtained through the courtesy of Dr. J. V. Aeschlimann, Hoffmann-LaRoche Ine.

${ }^{3}$ Work supported by a research grant from the National Institute of Arthritis and Metabolic Diseases, the U.S. Publie Health Service (A-1725). Acetyl- and butyrylthiocholine and DFP were obtained through the courtesy of Dr. Catherine O. Hebb, Institute of Animal Physiology, Agricultural Research Council, Cambridge, England. The diazonium salts tested in this research were furnished through the courtesy of Mrs. S. M. Neal, Imperial Chemical Industries Ltd., Manchester, England.

${ }^{4}$ Work supported by an Institutional Grant to the University of Michigan from the American Cancer Society. 
et al., '55), alkaline phosphatase (Allen, '56) and metachromasia (Picard and Vitry, '56).

The calcium-formol-induced fluorescence and the iodate reaction have been shown to demonstrate the same adrenomedullary cells in several species (Eränkö, '55, '56). Direct and indirect evidence has been presented to show that the adrenomedullary cells which give either of these two reactions are specialized in the secretion of noradrenaline, while the remaining chromaffin cells produce and secrete adrenaline (Hillarp and Hökfelt, '53, '54, '55; Eränkö, '55, '56, '57; Allen, '56; Eränkö and Hopsu, '57).

Of the histochemical reactions listed above, the esterases are of particular interest since the secretory stimulus to the adrenal medulla is mediated by acetylcholine (Feldberg et al., '34), which is broken down by cholinesterases (see Chessick, '54). Coutinho et al. ('55) observed esterase-positive and esterase-negative parenchymal cells in the adrenal medulla of the rat. These authors made no attempt to determine which of the two types of adrenomedullary cells contained this esterase activity nor did they investigate in detail the nature of the esterase activity observed. Such a study is reported in the present paper.

\section{MATERIALS AND METHODS}

Healthy adult rats of the Wistar strain were used. The animals were killed by decapitation and the adrenals immediately removed and dissected free of adjacent adipose tissue.

\section{Topographic studies}

Unfixed adrenals were sectioned on a freezing microtome at $20 \mu$ with a cooled knife. The sections were either transferred directly into the substrate solution for the demonstration of enzyme activity or fixed for varying periods in a solution containing $4 \%$ formaldehyde and $1 \%$ anhydrous calcium chloride. The fixed sections were rinsed in distilled water and mounted on slides before being subjected to the histochemical procedure. 
Other adrenals were immersed in the calcium-formol solution for 2-3 hours. Sections were then eut at $20 \mu$ with a freezing microtome, rinsed in water, floated onto slides and allowed to dry.

Fluorescent cell islets were visualized in the medullary regions of sections of calcium-formol-fixed adrenals by fluorescence microscopy. Photomicrographs of the fluorescence were taken either of the dry sections or after mounting the sections in glycerol.

Acid phosphatase was demonstrated using a modification of Gomori's glycerophosphate method (Eränkö, '52). The $0.1 \mathrm{M}$ acetate buffer was adjusted to $\mathrm{pH} 4.7$ and sections were incubated for $1 / 2-1$ hour at $37^{\circ} \mathrm{C}$.

For the demonstration of esterases several methods were used :

1. Acetyl- and butyrylthiocholine. The method described by Koelle ('51) was followed with the omission of storage solutions. The incubation times varied, but 1 hour for acetylthiocholine and $1 \frac{1 / 2}{2}-2$ hours for butyrylthiocholine at $37^{\circ} \mathrm{C}$ were optimal.

2. Myristoyl choline. The method used was essentially that given by Pearse ('53). The $\mathrm{pH}$ of the substrate solution was adjusted to 7.8. This method proved capricious and long incubation times (up to 7 hours for formalin-fixed sections) were necessary.

3. Alpha-naphthyl acetate. The technique prescribed by Pearse ('53) was used, adjusting the $0.1 \mathrm{M}$ phosphate buffer to $\mathrm{pH}$ 7.4. Since signs of diffusion were observed when diazotized ortho-dianisidine (Brentamine Fast Blue B salt I.C.I. Ltd.) was used as a coupling agent at a concentration of $1 \mathrm{mg}$ per $1 \mathrm{~cm}^{3}$ of substrate solution, other diazonium salts at higher concentrations (up to $10 \mathrm{mg}$ per $1 \mathrm{~cm}^{3}$ of substrate) were tried. Increasing the concentration of the diazonium salt resulted in some inhibition of enzyme activity but greatly improved the sharpness of the localization. Diazotates of 5-nitro-ortho-anisidine (Brentamine Fast Red B Salt, I.C.J. Ltd.), ortho-dianisidine (Brentamine Fast Blue B Salt, I.C.I. 
Ltd.), 3-nitro-para-anisidine (Brentamine Fast Bordeaux GP Salt, I.C.I. Ltd.) and 4-amino-3:2'-dimethyl-azobenzene (Brentamine Fast Garnet GBC Salt, I.C.I. Ltd.) gave good results when concentrations of $5-10 \mathrm{mg} / \mathrm{cm}^{3}$ were used. Incubation for $15-20$ minutes at room temperature was satisfactory.

\section{Inhibitor studies}

Adrenals for inhibitor studies were fixed 12 hours at $4^{\circ} \mathrm{C}$ in $10 \%$ formalin buffered and made isotonic with a phosphate buffer system at $\mathrm{pH}$ 7.0. These tissues were sectioned at $20 \mu$ on a freezing microtome, washed briefly in distilled water and mounted on slides. After drying in air at room temperature for 3 hours, they were subjected to histochemical treatment.

For the demonstration of esterases the same substrates used in topographic studies were employed.

1. Acetyl-and butyrylthiocholine. The same method was used as in the topographic studies.

2. Myristoyl choline. The method prescribed by Pearse (53) was applied but a $0.005 \mathrm{M}$ final concentration of calcium chloride was substituted for cobaltous acetate and tris buffer (Pearse, 53) at a final concentration of $0.025 \mathrm{M}$ and $\mathrm{pH} 7.8$ was substituted for veronal buffer. Following incubation in the substrate solution sections were treated exactly as outlined by Gomori ('52) for the demonstration of lipase activity against Tween substrates. This modification yielded a grossly crystalline precipitate of lead sulfide but reduced the optimum incubation period to 2 hours. The large erystals rendered these preparations useless for topographic studies but they proved excellent for inhibitor studies.

3. Alpha-naphthyl acetate. Except for the use of Fast Red Salt RC (General Dyestuff Co.) at a concentration of $1 \mathrm{mg} / 1 \mathrm{~cm}^{3}$ of substrate the method was used as in the topographic studies.

The following inhibitors were employed: eserine sulfate at a concentration of $10^{-5} \mathrm{M}$; di-isopropylfuorophosphate (DFP) at various concentrations; dimethyl carbamate of (2-hydroxy5-phenyl benzyl) trimethyl ammonium bromide (Ro 2-0683) 
at various concentrations; and p-chlorphenylmethyl carbamate of m-dimethylaminophenol methyl bromide (Ro 2-1250) at various concentrations. Stock solutions of DFP were prepared in anhydrous propylene glycol. Stock solutions of Ro 2-0683, Ro 2-1250 and eserine sulfate were prepared in distilled water. Stock solutions of inhibitors were stored at $4^{\circ} \mathrm{C}$ and working solutions were prepared just before use. These inhibitors were incorporated, in proper concentrations, into substrate solutions. Prior to immersion in the substrate solutions sections were pre-incubated for 30 minutes at $37^{\circ} \mathrm{C}$ in appropriate inhibitor concentrations made up in buffer or in distilled water. Sections were incubated in the substrate solutions at $37^{\circ} \mathrm{C}$ except for alpha-naphthyl acetate substrates which were used at room temperature. Incubation for twice the optimum time (table 2) was employed (except in the case of alpha-naphthyl acetate substrates which were used at the optimum time) to obviate, in part, the influence of differences in enzyme activity upon total inhibition points. Effects of inhibitors were judged visually against two types of control sections; (1) control sections which had not been treated with any inhibitor and (2) control sections which had been treated with $10^{-5} \mathrm{M}$ eserine sulfate. These latter sections were employed in the belief that $10^{-5} \mathrm{M}$ eserine sulfate would cause complete inhibition of cholinesterase activity (Richter and Croft, '42) and that these sections should serve as "no cholinesterase blanks" for comparative studies. The inhibitor concentration giving total inhibition of cholinesterase activity as judged against an eserinized control section was recorded. No attempt was made to grade degrees of inhibition other than total inhibition. Inhibitor effects were evaluated on multiple sections from each of a minimum of three animals for each inhibitor-substrate combination.

\section{Electrophoretic studies}

Further characterization of adrenomedullary esterases was attempted through the use of starch gel electrophoresis. 
Electrophoresis was earried out on liver and on pooled samples of adrenal medullae dissected free of the adrenal cortex. These tissues were homogenized with a minimum volume of water. The homogenate was absorbed onto a small piece of filter paper which was inserted into a starch gel column according to the method of Smithies ('55). Esterase activity was demonstrated on the starch column after electrophoresis using alpha-naphthyl acetate and alpha-naphthyl butyrate as substrates as described by Hunter and Markert ('57). Starch gels at pH 7.0 were used.

\section{RESULTS}

\section{Distribution of esterase activity}

Esterase activity in the various parts of the adrenal gland is summarized in table 1. A positive reaction was observed in the capsule with all the methods used. On the other hand, the parenchymal cells of the cortex reacted in different ways toward different substrates. While the reaction was consistently positive with alpha-naphthyl acetate, no reaction was seen with acetylthiocholine, butyrylthiocholine or myristoyl choline. A substrate-dependent difference was also seen in the macrophages which were present in the medulla and/or in the deeper parts of the cortex. These cells exhibited a strong reaction with adpha-naphthyl acetate but did not react with acetylthiocholine or butyrylthiocholine. Difficulties involved in the myristoyl choline technique prevented certain localization of enzymatic activity in units as small as individual cells.

In other respects similar results were obtained with all four substrates. Ganglion cells, often gathered into small groups in the medulla, and coarse nerve fibers were always strongly positive. Medullary parenchymal cells were divisible into two categories, being either positive or negative in their reaction. The reactive parenchymal cells were gathered into groups of a shape and size similar to those formed by the fluorescent, iodate-positive and acid phosphatase-negative cells. These esterase-positive parenchymal cells were sur- 
rounded by the main bulk of the esterase-negative parenchymal cells.

\section{Esterase reactions in the two types of adrenomedullary cells}

Preliminary experiments in which pairs of adjacent sections were compared (calcium-formol-induced fluorescence vs. esterase demonstrated with alpha-naphthyl acetate; acid phosphatase vs. esterase demonstrated with acetylthiocholine; etc.) suggested that both fluorescent and non-fluorescent parenchymal cells of the adrenal medulla may show either strong or weak esterase activity and that there was no spatial relationship between acid phosphatase activity and esterase activity. Further studies proved this first impression to be incorrect. Comparison of adjacent sections was found to be of limited value since the islets of fluorescent, acid phosphatasenegative medullary cells were of irregular shape and were small as compared with the section thickness. The distribution pattern, therefore, changed from one section to the next.

To clarify this situation two different histochemical reactions were applied consecutively to the same section. After the distribution of calcium-formol-induced fluorescence in a section was registered by photomicrography the esterases could be localized in the same section and their distributions recorded by photomicrography. Similar photographic comparisons of acid phosphatase and esterase activity could be made in the same section. Also esterase activity splitting alpha-naphthyl acetate could be photographically compared in the same section with esterase activity splitting acetylthiocholine or butyrylthiocholine.

Figures 1-12 show 6 pairs of photomicrographs made as described above. Visual and photographic comparisons clearly demonstrated that the medullary cell islets which fluoresced after fixation in calcium-formol and which were essentially acid phosphatase negative exhibited a strong esterase activity toward all the four substrates used (figs. 1-10). The esterase activity of the remaining medullary cells, except that of 


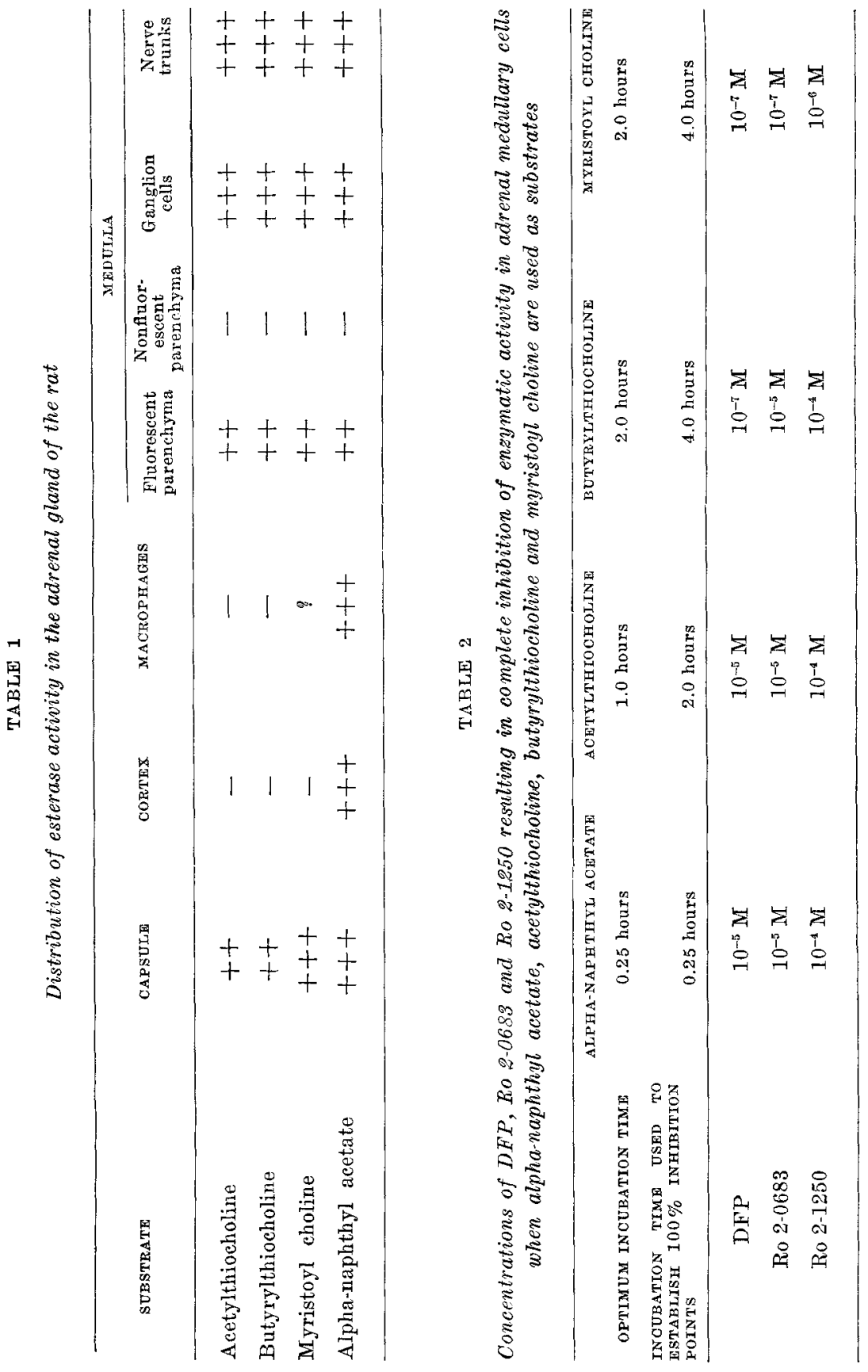


ganglion cells and coarse nerve fibers, was much weaker and could be demonstrated only after prolonged incubation in the substrates. The thiocholine and alpha-naphthyl acetate methods produced essentially the same results (figs. 11-12).

\section{Intracellular distribution of the esterase activity}

Differences in the distributions obtained with the different histochemical methods were observed at higher magnifications. The thiocholine methods, with optimal incubation times, showed enzymatic activity to be mainly concentrated in fine nerve fibers surrounding the parenchymal cells. With longer incubation times, particularly in the case of fresh, unfixed sections, enzymatic activity was observed also in the cytoplasm of parenchymal cells.

After incubation in myristoyl choline sufficient to produce a positive reaction in all fluorescent parenchymal cells the precipitate obtained was too dense to allow conclusions as to the accurate localization of the enzyme. Short incubation times produced granular precipitates in the cytoplasm of the parenchymal cells.

When alpha-naphthyl acetate was used as a substrate the fine distribution of activity depended upon the length of fixation as well as upon the diazonium salt employed. A fiber reaction similar to that obtained with the thiocholine methods was seen in calcium-formol fixed sections when a sufficient concentration of Fast Blue B Salt, Fast Red B Salt or Fast Bordeaux GP Salt was used. Substrates incorporating these diazonium salts yielded some cytoplasmic reaction on prolonged incubation. With Fast Garnet GBC a cytoplasmic reaction was seen, rather than the fiber reaction, even after formalin fixation.

At present it cannot be said whether the esterase activity in the parenchyma of the adrenal medulla is mainly associated with the nerve net, with the eytoplasm of the secretory cells, or with both. We are inclined to believe that this activity is present in both the nerve fibers and the cytoplasm of parenchymal cells and that the activity in the fibers is the stronger. 
Those areas of the adrenal medulla which were essentially esterase negative when optimum incubation times were employed showed esterase activity after prolonged incubation. Here, small nerve fibers were observed to give a positive reaction, particularly when the thiocholine and alpha-naphthyl acetate methods were employed. The lower esterase activity in these areas may be due, in part, to a less dense network of esterase-positive fibers. On the other hand, the esterase activity of the fibers in these low activity regions was weaker than the esterase activity associated with fibers found in high activity regions.

\section{Effect of inhibitors on the esterase reactions}

Eserine sulfate at a concentration of $10^{-5} \mathrm{M}$ completely inhibited enzyme activity in the medulla when acetylthiocholine, butyrylthiocholine and myristoyl choline were used as substrates. When alpha-naphthyl acetate was employed as substrate in the presence of $10^{-5} \mathrm{M}$ eserine sulfate a low but easily discernible residium of activity remained. This activity was homogeneously distributed in the cytoplasm of all parenchymal cells and all ganglion cells. These results indicate that adrenomedullary enzymatic activity against acetylthiocholine, butyrylthiocholine and myristoyl choline is exclusively of the cholinesterase variety since activity against these substrates was completely abolished by $10^{-5} \mathrm{M}$ eserine sulfate (Richter and Croft, '42). Adrenomedullary enzymatic activity against alpha-naphthyl acetate appears to consist of a major component of the cholinesterase variety which is abolished by $10^{-5} \mathrm{M}$ eserine sulfate and a minor eserine resistant component belonging to the aliesterase variety.

Further characterization of the eserine sensitive enzymes in the adrenal medulla was made possible by use of other inhibitors. Inspection of table 2 reveals two properties of the eserine sensitive enzymes hydrolyzing alpha-naphthyl acetate, acetylthiocholine, butyrylthiocholine and myristoyl choline. First, a separation of eserine sensitive enzymatic activity 
against alpha-naphthyl acetate and acetylthiocholine vs. butyrylthiocholine and myristoyl choline can be made on the basis of behavior following treatment with DFP. Cholinesterase activity against the former substrates is totally inhibited by $10^{-5}$ M DFP while activity against the latter two substrates is totally inhibited by $10^{-7} \mathrm{M}$ DFP. Second, a further separation of eserine sensitive esterolytic activity in the adrenal medulla may be made on the basis of behavior following treatment with Ro 2-0683 and Ro 2-1250. Eserine sensitive enzyme activity against alpha-naphthyl acetate, acetylthiocholine and butyrylthiocholine is totally inhibited by $10^{-5}$ M. Ro 2-0683 and $10^{-4} \mathrm{M}$ Ro 2-1250 while this activity against myristoyl choline is totally inhibited by $10^{-7} \mathrm{M}$ Ro 2-0683 and $10^{-6}$ M Ro 2-1250. Hence, eserine sensitive enzymes active against alpha-naphthyl acetate, acetylthiocholine and butyrylthiocholine are distinct from those active against myristoyl choline.

On the basis of these inhibitor studies three categories of eserine sensitive enzyme activity may be established. Group I enzymes are active against alpha-naphthyl acetate and acetylthiocholine and have an inhibitor profile of $10^{-5} \mathrm{M}$ DFP; $10^{-5}$ M Ro 2-0683; 10-4 M Ro 2-1250. Group II enzymes are active against butyrylthiocholine and have an inhibitor profile of $10^{-7} \mathrm{M}$ DFP; $10^{-5} \mathrm{M}$ Ro $2-0683 ; 10^{-4} \mathrm{M}$ Ro 2-1250. Group III enzymes are active against myristoyl choline and have an inhibitor profile of $10^{-7}$ M DFP; $10^{-7}$ M Ro 2-0683; $10^{-6}$ M Ro 2-1250. The possible importance of the number of carbon atoms in the ester group of the substrates is emphasized in this scheme.

Within any substrate-inhibitor category all medullary cells showing eserine sensitive esterolytic activity responded to the inhibitor in the same fashion. Esterase activity in cells of the eapsule and in macrophages was totally inhibited by $10^{-5} \mathrm{M}$ eserine sulfate. Enzyme activity against alpha-naphthyl acetate in cells of the adrenal cortex was unaffected by $10^{-5} \mathrm{M}$ eserine sulfate. Di-isopropylfuorophosphate, Ro 2-0683, and Ro 2-1250 at concentrations of $10^{-5} \mathrm{M}$ exerted slight inhibitory 
action on activity in adrenocortical cells when alpha-naphthyl acetate was employed. No attempt was made to evaluate the effect of DFP, Ro 2-0683, and Ro 2-1250 on esterase activity in capsule cells and in macrophages.

\section{Electrophoretic separation of different esterases}

Zymograms of adrenal medulla and liver showed a large number of reactive bands when alpha-naphthyl acetate and alpha-naphthyl butyrate were used as substrates (fig. 13). In both tissues the pattern of the bands showing esterase activity appeared to be dependent upon the substrate employed. Bands LM-2, LA-2, AMB-1 and AMA-1 were probably eaused by activity of the same esterase. Zymograms of rat serum showed an esterase positive band coinciding with these bands. This observation indicated that much or all of the esterase activity seen in these bands was due to contamination of homogenates by serum. Zymograms of laked rat red blood corpuscles showed no appreciable esterase activity. Therefore, none of the bands demonstrated appeared to be due to contamination of homogenates by blood corpuscles.

When alpha-naphthyl butyrate was used as substrate it appeared that the esterase bands demonstrable in homogenates of adrenal medulla were identical to certain of those demonstrable in homogenates of liver. Thus liver bands LB-6, LB-9 and LB-11 respectively coincided with adrenal medullary bands AMB-2, AMB-3 and AMB-4. When alpha-naphthyl acetate was employed as substrate no clear cut correlation could be made between esterase positive bands found in zymograms of adrenal medulla and liver. Failure to establish such correlation may indicate the presence of distinctly different esterases in these two tissues.

Several attempts were made to determine the effect of eserine sulfate upon the activity of esterases present in zymograms of adrenal medulla. Eserine sulfate at $10^{-5} \mathrm{M}$ and $10^{-4}$ $M$ was incorporated into the starch columns and into the substrate-diazonium salt mixture used for enzyme localization. No inhibition was observed when $10^{-5} \mathrm{M}$ eserine sulfate was 
employed and $10^{-6}$ eserine sulfate inhibited all bands slightly. These facts suggest that only enzymes of the aliesterase variety were demonstrated under these conditions. Failure to demonstrate cholinesterases in these zymograms may be attributed to any of several possibilities: (1) these enzymes may be bound to particles too large to migrate in starch columns or (2) they may be present as desmo-enzymes, or (3) they may not survive the procedures necessary to produce successful zymograms.

An important question concerns the relationship between these eserine insensitive enzymes demonstrated in zymograms of adrenal medulla and those eserine insensitive enzymes demonstrated in tissue sections. The production of successful zymograms probably requires the presence of lyo-enzymes whereas the production of successful cytochemical localizations requires the presence of desmo-enzymes or the binding of enzyme protein to cytoplasmic structures. It appears that zymograms may demonstrate a category of esterase activity in the adrenal medulla which is distinct from that seen in cytochemical preparations. The use of formalin as a fixative, however, may render insoluble some lyo-enzymes, thus some of the esterases seen in zymograms may also have been demonstrated cytochemically in the tissue sections.

Zymograms comparing the pattern of esterase activity found in homogenates of adrenal medulla and adrenal cortex gave remarkably similar results. The similarity of zymograms derived from these two tissues may be due, in part, to contamination of medullary samples by cortical cells. It seems unlikely, however, that contamination from cortical cells could contribute greatly to the pattern observed in zymograms of adrenal medulla. The lyo-aliesterases present in these two tissues may well be quite similar.

\section{DISCUSSION}

The above results confirm the work of Coutinho et al. ('55) who reported a discontinuous distribution of esterase in the adrenal medulla of the rat. In addition, the cells which pre- 
sumably secrete noradrenaline have been shown to exhibit stronger esterase activity than the cells which presumably secrete adrenaline. Thus, not only do these two cell types differ in their esterase activity but, as mentioned previously, earlier work showed that they differ characteristically under a battery of other histochemical techniques.

The effect of eserine sulfate upon enzymatic activity against the substrates employed in this study leaves little doubt that the major component of this activity belongs to the cholinesterase or eserine sensitive esterase category (Chessick, '54). The effects obtained with the other inhibitors (DFP, Ro 2-0683 and Ro 2-1250) are not so readily interpreted. Results obtained with DFP appear to lend themselves to interpretation along the lines proposed by Koelle ('50). According to this scheme $10^{-6} \mathrm{M}$ DFP completely inhibits "pseudo" cholinesterase activity. Thus, in the present study it might be assumed that activity against alpha-naphthyl acetate and acetylthiocholine would belong to the specific cholinesterases while activity against butyrylthiocholine and myristoyl choline would belong to the "pseudo" cholinesterases. Effects obtained with Ro 2-0683 and Ro 2-1250, however, indicate that enzymes active against alpha-naphthyl acetate, acetylthiocholine and butyrylthiocholine form one group and that enzymes active against myristoyl choline form another group. These results suggest that a simple classification of eserine sensitive enzymatic activity in the adrenomedullary tissue cannot be achieved on the basis of the methods employed here. The apparent role of the length of the carbon chain in the ester group of the substrates used by us is suggestive but further studies are required before its importance can be evaluated. We are inclined to believe, as Chessick ('54), that eserine sensitive esterases form a family of enzymes with overlapping properties.

Electrophoretic studies point to a similar degree of complexity in the case of the eserine resistant enzymatic activity against alpha-naphthyl acetate and alpha-naphthyl butyrate. In these studies a minimum of 4 distinct eserine resistant es- 
terases were demonstrated in the adrenal medulla. These methods have shown other tissues to be equally complex in their esterolytic composition (Hunter and Markert, '57).

The presence of higher esterase activity in noradrenalinesecreting cells than in adrenaline secreting cells is perplexing. If, as our results indicate, much of the esterase activity is connected with the nerve fibers surrounding the parenchymal cells then the discontinuous distribution of the enzyme could be accounted for, in part, if the noradrenaline secreting cells were surrounded by a greater number of nerve fibers than the adrenaline secreting cells. There is an extensive literature on the innervation of the adrenal medulla (see Stöhr, '57) but we have not been able to find reports of different types of cell groups as regards the density of the nerve fiber net surrounding them. Since most of the neurohistological studies on this tissue have been made without knowledge of the presence of two types of parenchymal cells, such a difference may easily have escaped notice.

Although the esterase activity of the adrenal medulla may be associated with the breakdown of acetylcholine liberated during nervous stimulation, this enzyme may also have other functions. Esterase might be involved in the processes of synthesis and secretion by the chromaffin cells. If this were so, the difference in esterase activity between the noradrenaline and adrenaline producing cells would be easier to understand. That differences in metabolism exist between these two types of cells is indicated by the observation that the noradrenaline cells exhibit a weak acid phosphatase activity present in the adrenaline cells of the rat adrenal medulla (Eränkö, '51, '52). Studies of alterations in the activity of various adrenomedullary enzymes under increased or decreased secretory activity would be of interest. Recent study (Allen, '56) has demonstrated that alkaline phosphatase activity in the adrenal medulla of the mouse may be selectively elevated in adrenaline or noradrenaline cells during increased secretion. Whatever the significance of the difference in the esterase activity between adrenaline and noradrenaline se- 
creting cells, our results strengthen the view that these cells are the result of a divergent differentiation and do not represent functional modulations of a common cell type.

Of interest would be a survey of the pattern of esterase activity in the adrenal medulla of other specices. That generalization from one species to another cannot be made is indicated by results obtained with the acid phosphatase method, which clearly discriminates between the two types of adrenomedullary cells in the rat (Eränkö, '51, '52), but fails to do so in the eat (Eränkö, '55; Hillarp and Falck, '56) or in the mouse (Allen, unpublished data).

\section{SUMMARY}

The distribution of esterase activity in the adrenal medulla of normal rats was studied histochemically. Acetylthiocholine, butyrylthiocholine, myristoyl choline and alphanaphthyl acetate were used as substrates. Characterization of the esterase activity observed was achieved through the use of eserine sulfate, di-isopropylfluorophosphate, dimethyl carbamate of (2-hydroxy-5-phenyl benzyl) trimethyl ammonium bromide (Ro 2-0683) and p-chlorphenyl methyl carbamate of m-dimethylaminophenol methyl bromide ( $R_{0} 2-1250$ ) as well as by starch electrophoresis.

All the substrates gave a positive reaction in ganglion cells and coarse nerve fibers but only some of the medullary parenchymal cells were reactive. The esterase-positive areas of the medullary parenchyma were found to correspond to the areas which fluoresced after calcium-formol fixation and which were acid phosphatase-negative. These relationships were demonstrated by applying two histochemical methods consecutively to the same tissue section. Previous work has suggested that this fluorescent positive and acid phosphatase negative cell type is associated with noradrenaline secretion. Thus, it appears that high esterase activity is associated with noradrenaline secreting cells and low esterase activity with adrenaline secreting cells. The esterase activity in the medullary parenchyma was localized principally in the net of 
fine nerve fibers surrounding the parenchymal cells but activity was also present in the cytoplasm of the parenchymal cells themselves.

Eserine sulfate at a concentration of $10^{-5} \mathrm{M}$ completely abolished activity against acetylthiocholine, butyrylthiocholine and myristoyl choline and markedly inhibited enzyme activity against alpha-naphthyl acetate. Fnzymes acting against the former three substrates are, therefore, exclusively of the cholinesterase type while the major activity against alphanaphthyl acetate also belongs to this group and the minor activity against alpha-naphthyl acetate seems to be of the aliesterase group. The remaining inhibitors employed failed to give a clear cut separation of the eserine sensitive esterolytic activities present in this tissue but indicated that the enzymes active against the substrates employed form a series with overlapping properties.

Starch electrophoretic studies indicated that there are a minimum of 4 enzymes showing esterolytic activity present in the adrenal medulla. The activity of these enzymes demonstrable in starch electrophoretic studies was not materially affected by $10^{-\check{s}} \mathrm{M}$ eserine sulfate.

\section{LITERATURE CITED}

ALLEN, J. M. 1956 The influence of cold, inanition and insulin shock upon the histochemistry of the adrenal medulla of the mouse. J. Histochem. Cytochem., 4: 341-346.

Chessick, R. 1954 The histochemical specificity of cholinesterases. J. Histochem. Cytochem., 2: 258-273.

Coltinho, H. B., B. I. Baker, J. F. Kent, E. C. Pliske and J. G. Van Dyke 1955 Esterases of the adrenal gland after hypophysectomy and total body roentgen radiation. Univ. Mich. Med. Bull., 21: 391-399.

ERÄNKö, O. 1951 On the histochemistry of the rat adrenal medulla. Acta physiol. Scand., 25 Supp. 89:22-23.

1952 On the histochemistry of the adrenal medulla of the rat, with special reference to acid phosphatase. Acta anat., 16, Supp. 17: 1-60. 1955 Distribution of adrenaline and noradrenaline in the adrenal medulla. Nature, 175: 88 .

1955 Distribution of fluorescing islets, adrenaline and noradrenaline in the adrenal medulla of the hamster. Acta endocrinol., 18: $174-179$.

1955 Distribution of fluoreseing islets, adrenaline and noradrenaline in the adrenal medulla of the cat. Acta endocrinol, $18: 180-188$. 
ER̈̈NKö, O. 1955 Histochemistry of noradrenaline in the adrenal medulla of rats and mice. Endocrinology, $57: 363-368$.

1956 Histochemical demonstration of noradrenaline in the adrenal medulla of the hamster. J. Histochem. Cytochem., $4: 11-13$.

1957 Distribution of adrenaline and noradrenaline in the hen adrenal gland. Nature, 179:417-418.

ERäNKö, O., AND V. HoPsu 1958 Effect of reserpine on the histochemistry and content of adrenaline and noradrenaline in the adrenal medulla of the rat and the mouse. Endocrinology, 62: 15-23.

FeldberG, W., B. Minz and H. Tzudzimura 1934 The mechanism of the nervous discharge of adrenaline. J. Physiol., 81: 286--304.

Gomori, G. 1952 Microscopic Histochemistry. The University of Chieago Press, Chicago.

Hillarp, N.A., and B. FAlcK 1956 Localization of acid phosphatase in the adrenal medullary cell. Acta endocrinol., 22: 95-106.

Hillarp, N.-Ã., AND B. Hökfelt 1953 Evidence of adrenaline and noradrenaline in separate adrenal medullary cells. Acta physiol. Scand., 30:55-68. 1954 Cytological demonstration of noradrenaline and the suprarenal medulla under conditions of varied secretory activity. Endocrin$0 \log y, 55: 255-260$.

1955 Histochemical demonstration of nonadrenaline and adrenaline in the adrenal medulla. J. Histochem. Cytochem., 3: 1-5.

Hunter, R., and C. Markert 1957 Histochemical demonstration of enzymes separated by zone electrophoresis in starch gels. Science, 125: 12941295.

KOELIE, G. B. 1950 The histochemical differentiation of types of cholinesterases and their localizations in tissues of the cat. J. Pharm. Ther., 100: $158-179$.

1951 The elimination of diffusion artifacts in the histochemical localization of cholinesterases and a survey of their cellular distributions. J. Pharmacol. Exp. Ther., 103: 153-171.

Pearse, A. G. E. 1953 Histochemistry, Theoretical and Applied. J. \& A. Churchill Ittd, London.

PICARd, D., AND G. VtTRY 1954 Les phosphatases acides dans les deux catégories cellulaires de la médullosurrénale. Compt. Rend. Soc. Biol., 148: $556-558$.

1956 Métachromasie et phosphatases, acides dans la médullo-surrénale. Ann. Histochem., 1: 19-25.

Picard, D., G. Vitry and G. Chambost 1955 Sécrétion adrénalinique et dimorphisme cellulaire de la médullo-surrénale. Compt. Rend. Assoc. Anat., 41: 531-539.

Richter, D., AND P. CrofT 1942 Blood esterases. Biochem. J., 36: 746-757.

Smithies, O. 1955 Zone electrophoresis in starch gels: group variations in the serum proteins of normal aduits. Biochem. J., 61:629-641.

SтöнR, J., JR. 1957 Mikroskopische Anatomie des vegetativen Nervensystems. Handb. d. mikr. Anat. d. Menschen, IV/5: 270-283. Springer; Berlin, Göttingen \& Mümehen. 
PLATES 
PLATE 1

EXPLANATION OF FIGURES

1 Calcium-formol-induced fluorescence of rat adrenal. Fluorescent medullary islets are clearly visible. Dark areas are empty blood vessels. Cortex is visible in both upper corners. $\times 95$.

2 Same section after demonstration of cholinesterase with the acetyltbiocholine method. Incubation for 1 hour. Transmitted light of $405 \mathrm{~m} \mu$ mercury line. Outlines of fluorescent islets drawn with India ink. Note the strongly positive ganglion corresponding to a non-fluorescent area in the center. $\times 95$.

3 Caleium-formol-induced fluorescence of adrenal medulla. $\times 95$.

4 Same section after demonstration of cholinesterase with myristoyl eholine. Incubation for 7 hours. Transmitted white light. Note the positive reaction in non-fluorescent areas (nerve cells and fibers). $\times 95$.

5 Caleium-formol-induced fluoreseenee. Cortex in lower margin. $\times 95$.

6 Same section after demonstration of cholinesterase with the butyrylthiocholine method. Incubation for $1 \frac{1}{2}$ hours. Transmitted light of $405 \mathrm{~m} \mu$ mercury line. Note the ganglion in a non-fluoresent area and the nerve net around it. $\times 95$. 

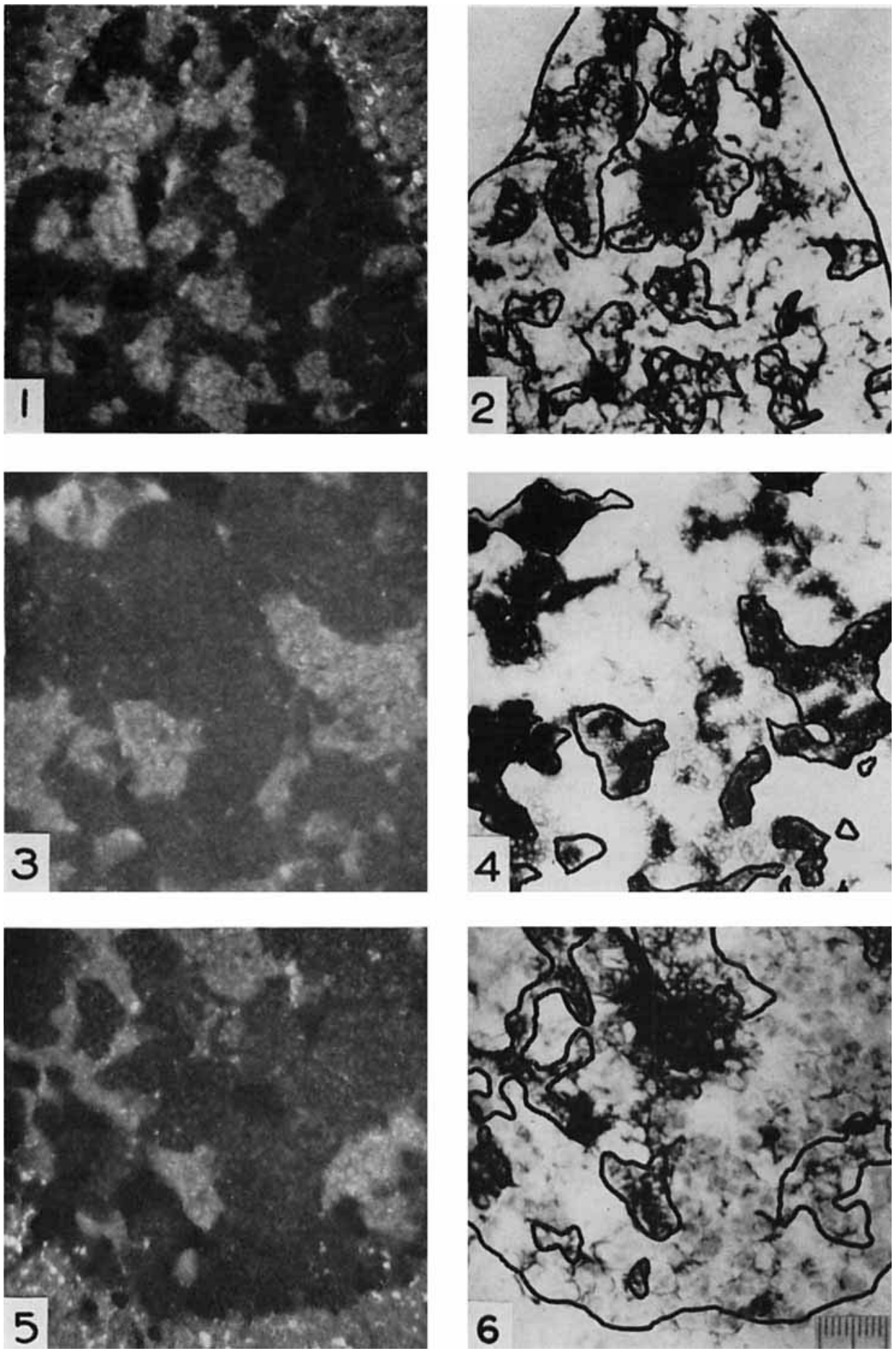
PI.ATE 2

EXPLANATION OF FIGURES

7 Calcium-formol-induced fluoresenee. Cortex in upper margin. $\times 95$.

8 Same section after demonstration of esterase with alpha-naphthyl acetate. Incubation for $20 \mathrm{~min} . \times 95$.

9 Distribution of acid phosphatase in adrenal medulla. Ineubation for $45 \mathrm{~min}$. Negative cell islets clearly visible. Blood vessels white. $\times 95$.

10 Same section after demonstration of esterase with alpha-naphthyl acetate. Incubation for $20 \mathrm{~min}$. Acid phosphatase negative areas covered with a positive esterase reaction. $\times 95$.

11 Distribution of cholinesterase in adrenal medulla. Acetylthiocholine. Ineubation for 1 hour. Photographed at $405 \mathrm{~m} \mu$ to increase contrast. $\times 95$.

12 Same section after ineubation in alpha-naphthyl acetate for $20 \mathrm{~min}$. Photographed in white light, in which the yellow color of the thiocholine precipitate produces poor contrast. $\times 95$. 

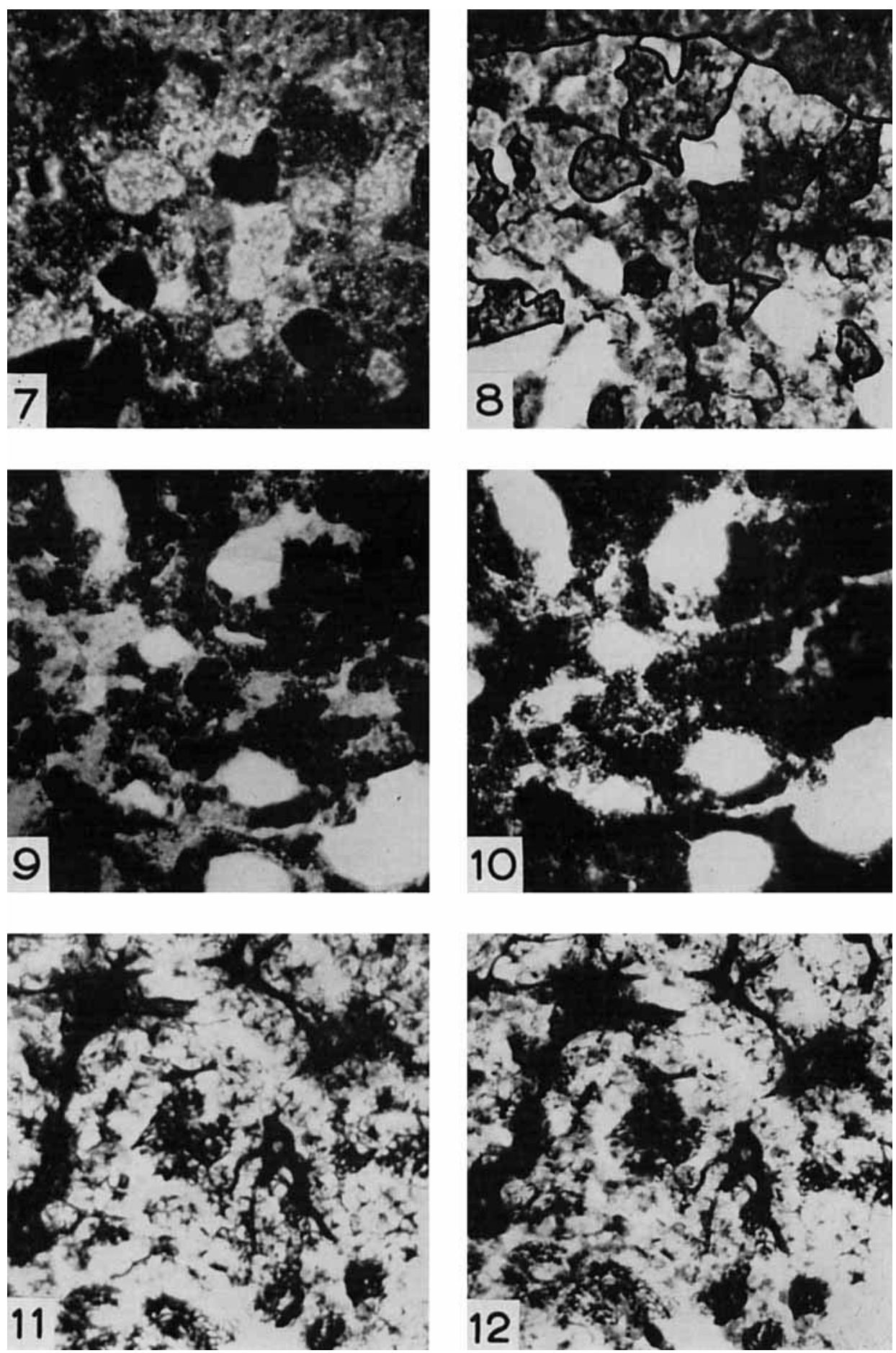


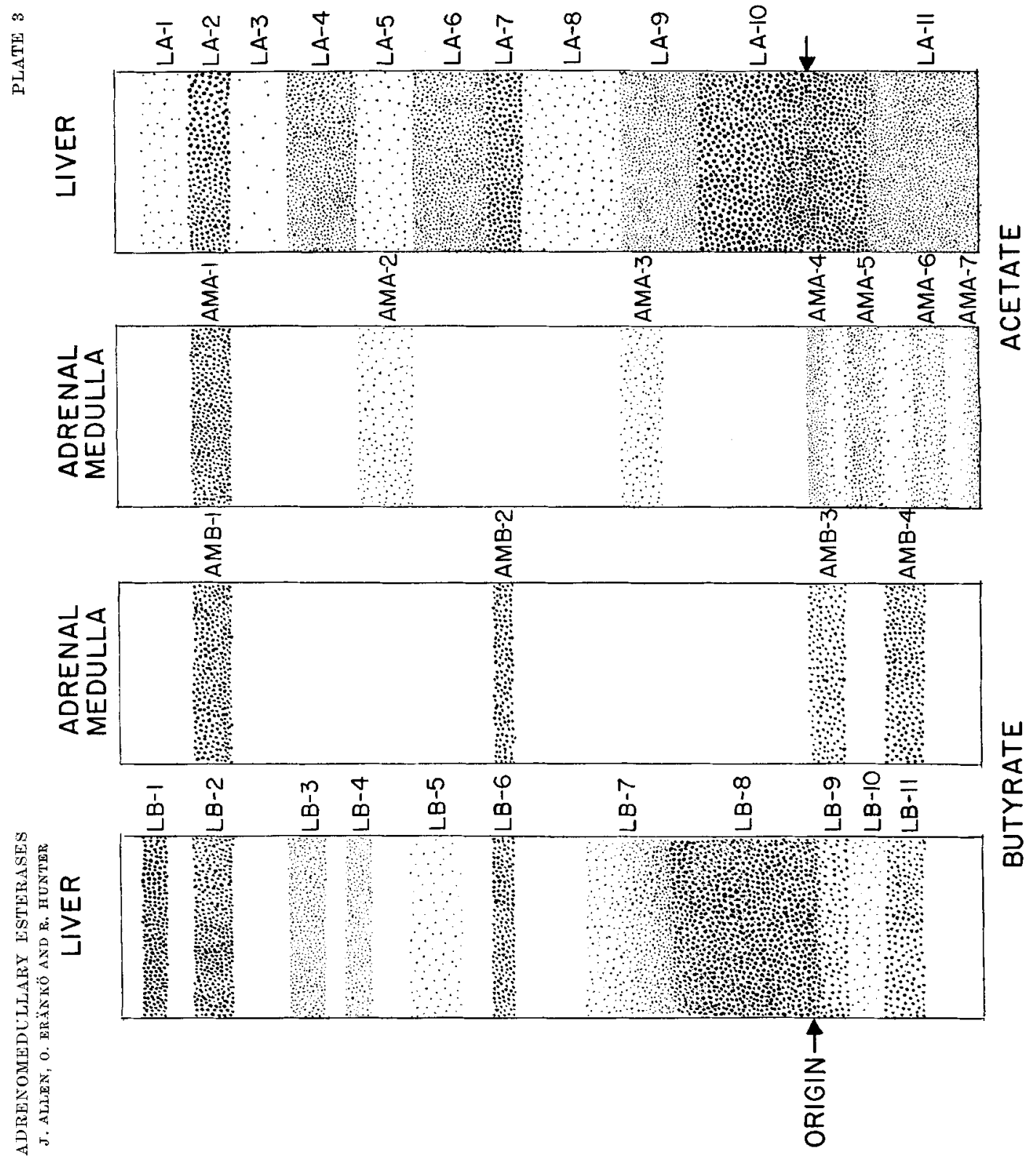

